\title{
Immanence, Pluralism, and Politics ${ }^{\mathrm{i}}$
}

\author{
Matthew J. Moore
}

The article examines whether theories based on an immanent worldview-roughly, one that denies the existence of transcendent principle or agents relevant to human life —offer a better solution to the problems of political pluralism than do transcendent theories. After reviewing three such theories-one from Michael Hardt and Antonio Negri, one from Gilles Deleuze and Félix Guattari, and one from William Connollythe author argues that theories like Connolly's, which both make positive claims and explicitly acknowledge the contestability of those claims, are the most defensible. At the same time, even those theories run into the problems of transcendent theories, especially relying on assumptions they cannot prove. Thus, the author suggests that we may need to be more modest in our expectations of how persuasive any such theory can be. [Article copies available for a fee from The Transformative Studies Institute. E-mail address: journal@transformativestudies.org http://www.transformativestudies.org (C2011 by The Transformative Studies Institute. All rights reserved.]

KEYWORDS: Immanence, Pluralism, Michael Hardt, Antonio Negri, Gilles Deleuze, William Connolly.

\footnotetext{
${ }^{\mathrm{i}}$ Earlier versions of this paper were presented at the 2008 American Political Science Association Meeting and the 2006 Western Political Science Association. I thank my fellow panelists for their helpful feedback on those occasions. I also thank several reviewers for their extremely helpful comments.

ii Matthew J. Moore, Ph.D., is Assistant Professor of Political Science at Cal Poly State University (San Luis Obispo). He has published on value pluralism, the philosophy of Ludwig Wittgenstein, and the practice of political theory. Address correspondence to: Matthew J. Moore, Dept. of Political Science, Cal Poly State University, 1 Grand Avenue, San Luis Obispo, California 93407; e-mail: mmoore02@calpoly.edu.
} 